\title{
Soil quality index for agricultural areas under different levels of anthropopressure**
}

\author{
Agnieszka Klimkowicz-Pawlas*®i), Aleksandra Ukalska-Jaruga®, and Bożena Smreczak@ \\ Institute of Soil Science and Plant Cultivation - State Research Institute, Department of Soil Science Erosion and Land Protection, \\ Czartoryskich 8, 24-100 Puławy, Poland \\ Received September 16, 2018; accepted April 30, 2019
}

\begin{abstract}
A bstract. Different individual soil parameters or simple indices are widely used in soil quality evaluation, but this approach has many limitations. The aim of the study was to determine an integrated soil quality index in agricultural soils as affected by different levels of anthropopressure. The soil quality index was calculated through: the selection of the appropriate indicators for a minimum data set, score assignation for selected indicators and the integration of indicators in an index. The study was carried out in two areas under agricultural use with similar soil cover but with a different history and intensity of exposure to pollution input. Soil samples collected from the surface layer $(0-30 \mathrm{~cm})$ were analysed for physicochemical (i.e. texture, fractional composition of soil organic matter, $\mathrm{pH}$ ), and biological (respiration, dehydrogenase activity, microbial biomass and nitrification) properties and the levels of contaminants (16PAHs and heavy metals). The level of anthropopressure was assessed on the basis of pollutants emission indices. A statistical evaluation based on principal component analysis enabled the selection of indicators of significant importance to soil quality. The level of anthropopressure was found to be an important factor influencing soil quality; higher soil quality index values $(0.50)$ were determined for the area of low anthropopressure.
\end{abstract}

Keywords: soil quality, anthropopressure, minimum data set, agricultural soils, soil quality index

\section{INTRODUCTION}

The term "soil quality" first appeared in the scientific literature in the 1980s and since that time it has received much attention. A variety of definitions have been proposed for the term 'soil quality', ranging from the purely agricultural point of view to a more environmental perspective (Bastida

*Corresponding author e-mail: agnes@iung.pulawy.pl

**This work was financed by the National Science Centre (grant number UMO-2011/03/B/ST10/05015) and partly by Ministry of Agriculture and Rural Development (PL) State Programme, Task 1.3 (2016-2020). et al., 2008; Epelde et al., 2014; Vasu et al., 2016). Soil quality may be defined as 'the capacity of soil to function within ecosystem and land use boundaries to sustain biological productivity, maintain environmental quality, and promote plant and animal health' (Garrigues et al., 2012; Mukherjee and Lal, 2014; Rahmanipour et al., 2014). From an environmental perspective soil quality is 'the capacity of the soil to promote the growth of plants, protect watersheds by regulating infiltration, and prevent water and air pollution by buffering potential pollutants such as agricultural chemicals, organic wastes, and industrial chemicals' (Bünemann et al., 2018). Soil contamination is a widespread threat to proper soil functioning and its quality. The most important functions and services listed in the EU soil framework directive that may be affected, include biomass production, water flow and retention, solute transport and retention, physical stability support, retention and nutrient cycling, buffering and filtering potentially toxic metals, and the maintenance of biodiversity and habitat (Garrigues et al., 2012; Volchko et al., 2014). The maintenance of soil quality is critical for ensuring the sustainability of the environment, because only a healthy soil can potentially enable the entire ecosystem to function properly. Typically, the concept of soil quality is considered in order to evaluate the productivity of soils. In recent times, soil quality assessment has been increasingly incorporated into sustainable land management, environmental risk assessment, monitoring environmental change and land restoration (Bünemann et al., 2018). To date, soil quality assessment has remained a challenging issue, because soils present a high degree of variability in their properties and functions.

(C) 2019 Institute of Agrophysics, Polish Academy of Sciences 
Several methods of soil quality evaluation have been developed, including soil card design and test kits, geostatistical methods or soil quality index methods (Rahmanipour et al., 2014; Bünemann et al., 2018). In general, soil quality assessment is carried out by selecting a set of soil properties which are considered to be indicators of soil quality (Vasu et al., 2016). The use of different individual soil parameters (e.g. total organic $\mathrm{C}$, texture) or single indices (e.g. the metabolic quotient, the metabolic ratio) is a common approach utilized for the evaluation of soil quality. However, the use of one individual indicator or indices integrating only two parameters has many limitations and provides insufficient information about soil quality and degradation (Bastida et al., 2008; Masto et al., 2015). Therefore scientific attention has recently focused on the derivation of complex, multiparametric indices combining different parameters. A soil quality index (SQI) could be defined as a minimum set of parameters that provides numerical data concerning the capacity of a soil to carry out one or more functions (Garrigues et al., 2012; Asensio et al., 2013). The selection of a minimum soil data set (MDS) is based on either expert opinion (subjective), or mathematical and statistical (objective) methods (Bastida et al., 2008; Bünemann et al., 2018). In recent times, statistical data reduction by using multivariate techniques such as principal component analysis (PCA), redundancy analysis, discriminant analysis and multiple regression have become more common. Soil quality indices have been used to evaluate the impact of agricultural practices, crop production, soil management (Armenise et al., 2013; Rahmanipour et al., 2014; Bera et al., 2016; Vasu et al., 2016), and to a lesser extent to assess soil exposed to anthropogenic pressure (e.g. contamination).

The aim of the study was to determine a soil quality index in agricultural soils affected by pollution which indicated different levels of anthropopressure. Different physical, chemical and biological soil properties were considered as potential soil quality indicators. Beyond basic soil characteristics (i.e. texture, $\mathrm{pH}$, organic carbon content), the fractional composition of the soil organic matter and the level of pollution was included in the total data set. SQI was calculated by a weighted additive approach after the selection of a minimum soil data set.

\section{MATERIALS AND METHODS}

The study was carried out in 2013 in two agricultural regions with a similar soil cover (predominance of Cambisols and Luvisols), but with a different history and intensity of exposure to pollution. Area HAP $\left(115 \mathrm{~km}^{2}\right)$, located in Upper Silesia (Czerwionka municipality, southwestern Poland), combines both typical urban, industrial, postindustrial and agricultural areas. Soil contamination in this region is mainly a result of fossil fuel combustion, waste recovery, road transport, long-term (over 100 years) coke production and previous coal mining activity. Area LAP $\left(108 \mathrm{~km}^{2}\right)$, located in the Lublin region (Frampol municipality, eastern Poland), is a typical agricultural region, remote from pollution sources, where soils are predominantly used for agriculture and horticulture. The climate in the investigated areas is influenced by continental air masses. The average yearly precipitation and temperature are $719 \mathrm{~mm}$ and $8.9^{\circ} \mathrm{C}$ for area HAP, and $640 \mathrm{~mm}$ and $7.8^{\circ} \mathrm{C}$ for area LAP, respectively. Pollutant emission indices (Central Statistical Office, 2015) were used for the assessment of the anthropopressure level in both regions. A more detailed description of the study area may be found in KlimkowiczPawlas et al. (2017).

The soil samples (area HAP, $n=43$; area LAP $n=32$ ) collected from the surface layer $(0-30 \mathrm{~cm})$ of the agricultural soils were analysed for physical, chemical and biological properties and for the content of selected contaminants: PAHs and metals. The soil materials were air-dried at a temperature of $20 \pm 2^{\circ} \mathrm{C}$, sieved through a $2 \mathrm{~mm}$ sievemesh and stored in the dark at $16-18^{\circ} \mathrm{C}$ before chemical and physical analysis. Fresh soil samples for biological activity measurements were prepared according to the ISO 10381-6 (1993) method.

The soil particle-size distribution was analysed using the aerometric method (PN-R-04032, 1998), while the $\mathrm{pH}$ was measured potentiometrically in a $1: 2.5\left(\mathrm{~m} \mathrm{~V}^{-1}\right)$ suspension of soil in a $1 \mathrm{~mol} \mathrm{~L}^{-1} \mathrm{KCl}$ solution (ISO 10390, 2005). The total nitrogen content $\left(\mathrm{N}_{\mathrm{tot}}\right)$ was measured in a Vario Macro Cube $\mathrm{CN}$ analyser (Elementar Analysensysteme $\mathrm{GmbH})$ after dry combustion. The total organic carbon $\left(\mathrm{C}_{\text {org }}\right)$ content was determined by sulphochromic oxidation (ISO 14235, 1998), and the fractional composition of the soil organic matter including humic acids (HA), fulvic acids (FA) and humins (HU) was analysed using an adapted ISO 12782-4 (2012) method approved by the International Humic Substances Society (Swift, 1996). The 16 PAH compounds from the US EPA list were extracted with dichloromethane in an Accelerated Solvent Extractor (ASE 200, Dionex) and analysed using gas chromatography with a mass spectrometer (GC-MS) (Agilent Technologies, Santa Clara, CA). The quality control procedures included the analysis of certified reference material (CRM 131), laboratory control samples and solvent blanks. The recoveries for individual PAHs from CRM 131 were within $62-84 \%$, precision which was expressed in the form of a relative standard deviation (RSD) was in the range of $5-12 \%$, and the method quantification limit (MQL) ranged from 0.02 to $2.10 \mu \mathrm{g} \mathrm{kg}^{-1}$. The total concentration of three heavy metals $(\mathrm{Z}, \mathrm{Cd}, \mathrm{Pb})$ was determined using an inductively coupled plasma mass spectrometry (ICP-MS) technique after the wet digestion of soil samples in aqua regia (ISO 11466, 1995). The accuracy for metal analysis was $10 \%$ and the MQL values were $0.85,0.08$ and $0.01 \mathrm{mg} \mathrm{kg}^{-1}$ for $\mathrm{Zn}, \mathrm{Pb}$ and $\mathrm{Cd}$, respectively. 
The analysis of soil biological properties included four parameters. Basal microbial respiration (BR) was measured by titration method (ISO 16072, 2002), carbon dioxide evolution was measured after a $24 \mathrm{~h}$ incubation of the soil samples. The method of Casida et al. (1964), with triphenyltetrazolium chloride (TTC) as an electron acceptor, was applied to dehydrogenase (EC 1.1.1.1) activity (DHA) measurements. Microbial biomass $\left(\mathrm{C}_{\text {mic }}\right)$ was based on the substrate-induced respiration method (ISO 14240-1, 1997), in which $\mathrm{CO}_{2}$ evolution was assessed $6 \mathrm{~h}$ after the addition of the readily degradable substrate. The potential of nitrification (NIT) was determined according to a method which was described in detail by Maliszewska-Kordybach et al. (2007). Soil samples were mixed for $24 \mathrm{~h}$ with a mineral medium containing ammonium sulphate as a substrate, the amount of $\mathrm{NO}_{2}^{-}$formed was determined spectrophotometrically after the addition of a colour reagent containing sulphanilamide and N-(1-naphtyl)ethylene diamine dichydrochloride. All biological analyses were performed in triplicate and the results were expressed as an arithmetic mean of three measurements adjusted to the dry matter content of the soil.

The calculation of the soil quality index (SQI) included three steps: selection of the appropriate indicators for a minimum data set (MDS), score assignation for the selected indicators and the integration of the indicator scores into an overall index of soil quality (Rahmanipour et al., 2014; Volchko et al., 2014). The selection of indicators for the MDS was based on a principal component type of factoring (PCA) analysis, which was used as a data reduction tool. The varimax rotation of the factor loading matrix was applied, only the factors with eigenvalues $\geq 1$ were considered in the selection of indicators. Only the soil parameters which had a higher correlation with the principal component (PC) in PCA were considered in the MDS. However, when more than one variable was selected within a single PC, multivariate correlation coefficients were used to check for redundancy and correlation between the variables. Of the significantly correlated parameters, only one variable with the highest loading factor was included in the MDS. In the second step selected parameters were transformed into numerical scores which ranged from 0 to 1 through a linear scoring method (Armenise et al., 2013; Mukherjee and Lal, 2014). This scoring process was applied to the two regions (area LAP and area HAP) separately. Two types of assumptions were applied, the best soil functionality was associated with the high or low values of the indicator. For the 'more is better' parameters, each value of the indicator was divided by the highest observed value so that this value received a score of 1 ; for the 'less is better' indicators, the lowest observed value was divided by each observation such that the lowest value received a score of 1 . After scoring the parameters, an SQI value was calculated using the weighted additive approach according the following equation:

$$
S Q I=\sum w_{i} S_{i}
$$

where: $w_{i}$ is the weightage factor determined from the ratio of the total percentage of variance from each factor to the maximum cumulative variance coefficients of the principal component considered; $S_{i}$ is the score of each parameter in the minimum dataset.

All statistical analyses including basic statistical parameters analyses (mean, standard deviation, range, and coefficient of variation), PCA analyses and the determination of correlation coefficients were carried out using the Statgraphics Centurion programme (version XV, Statpoint Technologies). The differences in SQI between regions were also evaluated using a one-way analysis of variance (ANOVA, Duncan test, $\mathrm{p} \leq 0.05$ ).

\section{RESULTS AND DISCUSSION}

The level of anthropopressure in both regions was assessed on the basis of pollutant emission indices and the content of 16PAHs and three metals (Table 1). For the HAP area the anthropogenic indices amounted to 6827 and $1084 \mathrm{~kg}$ year ${ }^{-1} \mathrm{~km}^{-2}$ for total dust emission and dust emission from industrial sources, respectively (Central Statistical Office, 2015). Additionally this region was characterized by a high population density (366 persons per $\mathrm{km}^{-2}$ ) (Maliszewska-Kordybach et al., 2010; KlimkowiczPawlas et al., 2017). The emission indices noted for the LAP area were several times lower (995 and $111 \mathrm{~kg}_{\text {year }}{ }^{-1} \mathrm{~km}^{-2}$, respectively). Soils from both of the investigated regions did not differ significantly in their basic properties (texture, $\mathrm{pH}$ and nitrogen content). Most of the soils exhibited relatively high acidity values (average $\mathrm{pH}$ of 5.2-5.5), and low $\mathrm{N}_{\text {tot }}$ content (mean 1.72-1.83 $\mathrm{g} \mathrm{kg}^{-1}$ ). A high degree of variability was observed for $\mathrm{C}_{\text {org }}$ (CV up to $145 \%$ ), as well as for metals and PAHs content (CV up to $375 \%$ ) (Table 1). The total concentration of pollutants in the soils from the HAP area was much higher (5-fold for metals and over 15-fold for PAHs) compared to the LAP area and reached levels of $140.08,1.09,54.25$, and $224.13 \mathrm{mg} \mathrm{kg}^{-1}$ for $\mathrm{Zn}, \mathrm{Cd}, \mathrm{Pb}$ and 16PAHs, respectively. Such content of pollutants in this region was connected with a high degree of anthropogenic pressure related to long-term intensive industrial activity, i.e. coal mining, energy production and waste recovery. A wider discussion of the potential sources of PAHs was presented in an earlier work of Maliszewska-Kordybach et al. (2010) and Klimkowicz-Pawlas et al. (2017). A large variability in total organic carbon was also observed, the $\mathrm{C}_{\text {org }}$ content in soils from the HAP area ranged from 6.97 to $187.16 \mathrm{~g} \mathrm{~kg}^{-1}$. In the fractional composition of organic carbon the predominant fraction was HU (Table 1). Humins are the most stable fraction of humic substances, they are resistant to microbial degradation and demonstrate a high sorption capacity and ability to retain contaminants. Our observations were in line with the findings of other authors (Watanabe et al., 2001; Tan 2014). 
Table 1. Descriptive statistics of soil properties used for soil quality assessment

\begin{tabular}{|c|c|c|c|c|c|c|c|c|c|c|c|}
\hline \multirow{2}{*}{ Parameters } & \multirow{2}{*}{ Units } & \multicolumn{5}{|c|}{ Area LAP $(\mathrm{n}=32)$} & \multicolumn{5}{|c|}{ Area HAP $(n=43)$} \\
\hline & & mean & $\min$ & $\max$ & SD & $\mathrm{CV}$ & mean & $\min$ & $\max$ & SD & $\mathrm{CV}$ \\
\hline Sand & $\%$ & 56 & 15 & 94 & 25 & 44 & 72 & 49 & 90 & 9 & 13 \\
\hline Silt & $\%$ & 39 & 5 & 82 & 22 & 56 & 27 & 9 & 45 & 8 & 32 \\
\hline Clay & $\%$ & 5 & 0 & 21 & 6 & 120 & 2 & 0 & 6 & 2 & 101 \\
\hline $\mathrm{N}_{\text {tot }}$ & $\mathrm{g} \mathrm{kg}^{-1}$ & 1.72 & 0.75 & 5.05 & 1.05 & 61 & 1.83 & 0.76 & 11.67 & 2.00 & 109 \\
\hline $\mathrm{pH}_{\mathrm{KCl}}$ & - & 5.5 & 3.5 & 7.3 & 1.2 & 22 & 5.2 & 3.8 & 7.8 & 0.9 & 18 \\
\hline $\mathrm{C}_{\text {org }}$ & $\mathrm{g} \mathrm{kg}^{-1}$ & 15.77 & 6.37 & 55.48 & 11.15 & 70 & 26.98 & 6.97 & 187.16 & 39.08 & 145 \\
\hline FA & $\mathrm{g} \mathrm{kg}^{-1}$ & 2.89 & 1.58 & 6.01 & 1.20 & 42 & 2.77 & 0.60 & 8.79 & 1.76 & 64 \\
\hline HA & $\mathrm{g} \mathrm{kg}^{-1}$ & 5.84 & 0.64 & 20.12 & 4.08 & 70 & 7.28 & 0.61 & 17.12 & 3.43 & 47 \\
\hline $\mathrm{HU}$ & $\mathrm{g} \mathrm{kg}^{-1}$ & 7.04 & 0.30 & 32.54 & 7.93 & 112 & 16.92 & 0.15 & 164.93 & 36.72 & 217 \\
\hline DHA & $\mu \mathrm{gTPFg}^{-1} \mathrm{dw}$ & 48.68 & 4.21 & 97.89 & 22.42 & 46 & 25.42 & 3.44 & 73.88 & 15.10 & 59 \\
\hline NIT & $\mu \mathrm{gNO}_{2}^{-} \mathrm{g}^{-1} \mathrm{dw} \mathrm{h}{ }^{-1}$ & 3.78 & 0.03 & 21.50 & 4.73 & 125 & 2.50 & 0.04 & 7.67 & 2.07 & 83 \\
\hline $\mathrm{BR}$ & $\mu \mathrm{gCO}_{2} \mathrm{~g}^{-1} \mathrm{dw} \mathrm{h}^{-1}$ & 3.40 & 0.79 & 9.72 & 2.14 & 63 & 2.72 & 0.72 & 7.68 & 1.77 & 65 \\
\hline $\mathrm{C}_{\text {mic }}$ & $\mu \mathrm{g} \mathrm{g}^{-1} \mathrm{dw}$ & 73.48 & 37.86 & 114.71 & 21.97 & 30 & 71.00 & 22.12 & 166.59 & 28.89 & 41 \\
\hline $\mathrm{Zn}$ & $\mathrm{mg} \mathrm{kg}^{-1}$ & 27.83 & 4.01 & 48.15 & 10.85 & 39 & 140.08 & 20.88 & 1092.22 & 205.04 & 146 \\
\hline $\mathrm{Cd}$ & $\mathrm{mg} \mathrm{kg}^{-1}$ & 0.24 & 0.06 & 0.58 & 0.11 & 44 & 1.09 & 0.06 & 9.33 & 1.57 & 144 \\
\hline $\mathrm{Pb}$ & $\mathrm{mg} \mathrm{kg}^{-1}$ & 14.00 & 6.52 & 27.57 & 4.55 & 32 & 54.25 & 15.40 & 416.68 & 70.72 & 130 \\
\hline 16РAH & $\mathrm{mg} \mathrm{kg}^{-1}$ & 0.65 & 0.10 & 4.35 & 0.88 & 134 & 11.27 & 0.38 & 224.13 & 42.28 & 375 \\
\hline
\end{tabular}

$\mathrm{N}_{\text {tot }}$ - total nitrogen content, $\mathrm{C}_{\text {org }}$ - total organic carbon content, FA - fulvic acids, HA - humic acids, HU - humins, DHA - dehydrogenase activity, NIT - potential of nitrification, $\mathrm{BR}$ - basal respiration, $\mathrm{C}_{\text {mic }}-$ microbial biomass; $\mathrm{Zn}, \mathrm{Cd}, \mathrm{Pb}$ and $16 \mathrm{PAHs}-\mathrm{zinc}$, cadmium, lead and polycyclic aromatic hydrocarbons content, respectively; SD - standard deviation, $\mathrm{CV}$ - coefficient of variation (\%), LAP - area of low anthropopressure, HAP - area of high anthropopressure.

Significant differences were found between the biological activities of the soil from the two regions studied. Dehydrogenase and nitrification activity was lower in the HAP area, on average by 48 and 34\%, respectively. Active microbial biomass and soil respiration was affected to a lesser extent (Table 1). Biological and biochemical soil properties are considered to be the essential factors affecting the fertility and quality of soils (Bastida et al., 2008; Epelde et al., 2014; Masto et al., 2015; Muhlbachova et al., 2015). Soil microorganisms participate in many soil processes and due to their short generation time and high surface-tovolume ratio they may react quickly to environmental changes (Maliszewska-Kordybach et al., 2007; Asensio et al., 2013; Bera et al., 2016). Potential nitrification reflects the activity of autotrophic ammonium oxidizing bacteria, which are very sensitive not only to soil environment conditions (temperature, $\mathrm{pH}$, substrate content), but also to soil contamination even at a very low concentration (Wyszkowska and Kucharski, 2004; Maliszewska-Kordybach et al., 2007; Epelde et al., 2014). Dehydrogenases are present in all living microbial cells, they rapidly degrade in the soil after the death of the cells and do not accumulate in soils, they provide a measure of the total oxidative activity of soil microorganisms (Bastida et al., 2008; Muhlbachova et al., 2015).
Different methods and approaches are reported in the literature as a tool for the selection of indicators for the minimum data set and calculation of soil quality indices. These methods are based either on expert opinion (Asensio et al., 2013; Masto et al., 2015), statistical and mathematical analysis (Armenise et al., 2013; Bera et al., 2016; Li et al., 2018), or a combination of both approaches (Mukherjee and Lal, 2014; Vasu et al., 2016; Bünemann et al., 2018). In our study the identification of MDS and the calculation of SQI was based on the method described earlier by Rahmanipour et al. (2014) and Vasu et al. (2016). A minimum data set was established through a principal component analysis performed using seventeen different soil parameters: physical (soil texture), chemical ( $\mathrm{pH}, \mathrm{N}, \mathrm{C}$ content, fractional composition of $\mathrm{C}_{\text {org }}$ and the level of soil contamination) and biological (enzymatic activity, nitrification potential, microbial respiration and biomass). The results obtained from PCA indicated four (LAP area) and five factors (HAP area) with eigenvalues $\geq 1$ (Table 2) thereby explaining 81 and $84 \%$ of the total variation, respectively. Soil variables from each $\mathrm{PC}$ factor were considered for the minimum data set. Eight different soil indicators $\left(\mathrm{N}_{\text {tot }}, \mathrm{C}_{\text {org }}, \mathrm{HA}, \mathrm{HU}, \mathrm{BR}\right.$, $\mathrm{C}_{\text {mic }}, \mathrm{Cd}$ and $\mathrm{Pb}$ ) were selected from PC 1 for the LAP area, while for the HAP area only five indicators (sand, $\mathrm{N}_{\mathrm{tot}}, \mathrm{C}_{\mathrm{org}}$, $\mathrm{HU}, \mathrm{C}_{\mathrm{mic}}$ ) were correlated with the first factor. However, a further analysis of multivariate correlation between 
Table 2. Principal components, eigenvalues and component matrix variables

\begin{tabular}{|c|c|c|c|c|c|c|c|c|c|}
\hline \multirow{2}{*}{ Parameters } & \multicolumn{4}{|c|}{ Area LAP $(n=32)$} & \multicolumn{5}{|c|}{ Area HAP $(n=43)$} \\
\hline & PC 1 & PC 2 & PC 3 & PC 4 & PC 1 & PC 2 & PC 3 & PC 4 & PC 5 \\
\hline Eigenvalue & 6.8 & 4.0 & 1.6 & 1.4 & 6.4 & 2.9 & 2.5 & 1.5 & 1.0 \\
\hline$\%$ Variance & 40.2 & 23.5 & 9.2 & 8.2 & 37.4 & 16.9 & 14.7 & 8.8 & 6.2 \\
\hline Cumulative variance & 40.2 & 63.8 & 73.0 & 81.2 & 37.4 & 54.3 & 69.0 & 77.8 & 84.0 \\
\hline \multicolumn{10}{|c|}{ Factor loadings (Rotated component matrix) } \\
\hline Sand & -0.267 & -0.264 & $\underline{-0.891}$ & -0.013 & -0.676 & 0.190 & -0.408 & -0.039 & -0.189 \\
\hline Silt & -0.289 & 0.123 & 0.884 & 0.014 & -0.366 & -0.022 & -0.019 & 0.167 & $\underline{0.864}$ \\
\hline Clay & -0.141 & 0.553 & 0.438 & -0.545 & 0.223 & -0.013 & -0.450 & -0.041 & 0.762 \\
\hline $\mathrm{N}_{\mathrm{tot}}$ & $\underline{0.980}$ & 0.019 & 0.020 & 0.073 & 0.819 & 0.109 & 0.490 & -0.106 & -0.181 \\
\hline $\mathrm{pH}_{\mathrm{KCl}}$ & 0.009 & 0.862 & 0.225 & 0.111 & -0.145 & 0.089 & 0.033 & $\underline{0.908}$ & 0.163 \\
\hline $\mathrm{C}_{\text {org }}$ & 0.973 & -0.043 & -0.054 & 0.107 & 0.920 & 0.239 & 0.193 & -0.102 & -0.091 \\
\hline FA & 0.427 & -0.438 & -0.211 & -0.030 & 0.217 & 0.131 & 0.798 & -0.216 & -0.227 \\
\hline HA & 0.790 & -0.024 & -0.219 & 0.326 & 0.321 & 0.266 & 0.638 & -0.302 & -0.227 \\
\hline HU & 0.956 & -0.015 & 0.017 & 0.033 & $\underline{0.938}$ & 0.223 & 0.108 & -0.070 & -0.065 \\
\hline DHA & 0.349 & 0.164 & 0.067 & $\underline{0.754}$ & -0.422 & 0.324 & 0.378 & -0.358 & -0.337 \\
\hline NIT & -0.027 & $\underline{0.877}$ & 0.166 & -0.144 & 0.023 & 0.066 & -0.150 & 0.880 & -0.045 \\
\hline BR & 0.731 & 0.598 & -0.027 & 0.139 & 0.265 & 0.115 & $\underline{0.821}$ & 0.088 & 0.002 \\
\hline $\mathrm{C}_{\mathrm{mic}}$ & 0.641 & 0.313 & 0.190 & -0.369 & 0.610 & 0.221 & 0.617 & 0.054 & -0.172 \\
\hline $\mathrm{Zn}$ & 0.403 & 0.419 & 0.724 & 0.036 & 0.019 & $\underline{0.971}$ & 0.132 & 0.042 & 0.009 \\
\hline $\mathrm{Cd}$ & 0.952 & -0.050 & 0.150 & 0.044 & 0.064 & 0.929 & 0.173 & 0.033 & -0.107 \\
\hline $\mathrm{Pb}$ & 0.835 & -0.161 & 0.356 & -0.063 & 0.115 & 0.950 & 0.161 & -0.015 & -0.124 \\
\hline $16 \mathrm{PAH}$ & -0.087 & -0.063 & 0.043 & 0.728 & 0.392 & 0.651 & -0.052 & 0.144 & 0.241 \\
\hline
\end{tabular}

$\mathrm{PC}$ - principal component; bold factor loadings were considered highly weighted and underlined bold values are selected in minimum data set. Other explanations as in Table 1.

Table 3. Pearson correlation coefficients for highly loaded parameters in PC 1 (example of HAP area, $n=43$ )

\begin{tabular}{llllll}
\hline & Sand & $\mathrm{N}_{\text {tot }}$ & $\mathrm{C}_{\text {org }}$ & $\mathrm{HU}$ & $\mathrm{C}_{\text {mic }}$ \\
\hline Sand & 1 & & & & \\
$\mathrm{~N}_{\text {tot }}$ & $-0.710^{*}$ & 1 & & & \\
$\mathrm{C}_{\text {org }}$ & $-0.593^{*}$ & $0.913^{*}$ & 1 & & \\
$\mathrm{HU}$ & $-0.577^{*}$ & $0.880^{*}$ & $0.994^{*}$ & 1 & 1 \\
$\mathrm{C}_{\text {mic }}$ & $-0.539^{*}$ & $0.817^{*}$ & $0.707^{*}$ & $0.658^{*}$ & \\
\hline
\end{tabular}

*Values statistically significant at $\mathrm{p}<0.001$. Explanations as under Table 1 .

these parameters indicated their close interrelationship and only $\mathrm{N}_{\text {tot }}$ and $\mathrm{HU}$ which have the highest factor loadings were retained in the MDS. An example of the correlation matrix for selected parameters within the first PC is shown in Table 3. A similar analysis was carried out for other factors - data not shown, which allowed for additional indicators such as NIT, sand and DHA for soils from the LAP area, and $\mathrm{Zn}, \mathrm{BR}, \mathrm{pH}$ and silt from the HAP area (Table 2) to be included in the MDS. The 'more is better' assumption was used for assigning a score to $\mathrm{N}_{\mathrm{tot}}$, HU, NIT, DHA, BR, $\mathrm{pH}$ and silt, and 'less is better' for sand and metals content.
Generally, the soil quality in the typical LAP agricultural region was mainly affected by total nitrogen, NIT and DHA, i.e. parameters which describe soil organic matter quality, the functional capability of the soil to supply nutrients to plants, and the microbial activity relevant to $\mathrm{N}$ cycling and the oxidation of organic compounds (Bünemann et al., 2018). In the HAP area of high anthroporessure, the highest factor loadings were for organic matter composition (mainly HU - the most stable fraction of organic matter), soil acidity, texture and the level of soil pollution. As stated by Masto et al. (2015), Vasu et al. (2016), and 


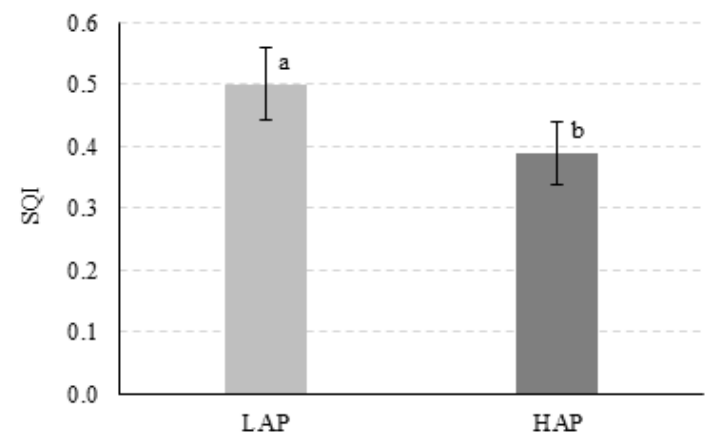

Fig. 1. Soil quality index (expressed as a mean value) for the area of low (LAP) and high (HAP) level of anthropopressure. Different letters indicate significant differences in SQI values in both regions (ANOVA Duncan's test, $\mathrm{p}<0.05$ ).

Li et al. (2018) the most common indicator used in SQI evaluation is the total organic carbon content, while studies which include the fractional composition of soil organic matter into MDS are rather rare (Asensio et al., 2013). Soil $\mathrm{pH}$ and texture (mainly clay content) are also frequently considered in the quality assessment of agricultural soils (Bastida et al., 2008; Armenise et al., 2013; Rahmanipour et al., 2014; Bünemann et al., 2018), however literature data concerning the use of the concentration of contaminants for SQI assessment are rather insufficient (Volchko et al., 2014). Soil $\mathrm{pH}$ affects the solubility and availability of nutrients and contaminants and affects microbial activity, in contaminated areas soil acidity may be an additional stress factor for soil microorganisms and increase their sensitivity to pollution (Maliszewska-Kordybach et al., 2007). The clay fraction influences carbon sequestration in soils, the adsorption and desorption of nutrients, the stability of soil aggregates and the retention of contaminants (Armenise et al., 2013); the low content of the clay fraction may result in a reduction in pollutant sorption, which increases their leaching and transport to the deeper soil layers and enhances their bioavailability (MaliszewskaKordybach et al., 2010). Additionally, the soil quality in the HAP area was related to soil respiration, which reflects the oxidative capacity of soil microorganisms and is influenced by the energy sources present in soils (Epelde et al., 2014; Muhlbachova et al., 2015). Soil processes i.e. nutrient cycling, organic matter decomposition, filtering and buffering are driven by the biochemical properties of the soil. Therefore, these properties are important indicators with which to monitor soil processes as they are more sensitive to changes in the environment than soil physical and che- mical parameters (Bastida et al., 2008; Bera et al., 2016). Soil respiration, alongside parameters such as microbial biomass, enzymatic activity or process-level based assays (nitrification), is the most commonly used indicator both in assessing soil quality and environmental risk (Myśków et al., 1996; Muhlbachova et al., 2015; Bünemann et al., 2018). However, soil biological properties are most frequently utilized as individual indicators in soil quality assessment (Epelde et al., 2014; Muhlbachova et al., 2015) and are rather seldom included in multiparametric quality indices (Myśków et al., 1996; Wyszkowska et al., 2013).

The parameters selected for the minimum data set were independent of each other, and after the assignment of a score and weighting value they were integrated into SQI (Fig. 1). The values of the soil quality index were in the range of $0.20-1.35$, with mean values of 0.50 for the LAP area and 0.39 for the HAP area. The results of ANOVA (Fig. 1) showed that the anthropopressure level significantly affected the SQI; higher values of this index $(+22 \%)$ were found in soils from the agricultural LAP area. However, the observed differences were rather small, which indicates that despite the high level of pollutants (Table 1) in the HAP area, soil quality in this region is also influenced by biological and physicochemical properties. Volchko et al. (2014) and Li et al. (2018) have both proposed soil classifications based on SQIs (Table 4), they distinguished five classes of soil quality: very poor, poor, medium, good and very good depending on the values of SQIs. In general, the quality of soils from the two regions varied from low to high, but the percentage share of soils in the individual quality grades differed distinctly (Fig. 2). Most soils from the area of high anthropopressure (HAP) had very low SQI values with an average value of 0.28 and were of very poor $(72 \%)$ and poor $(9 \%)$ quality according to the proposed system of $\mathrm{Li}$ et al. (2018). The soils classified in the good quality category consisted of only $14 \%$ of the total area (Fig. 2). In contrast, in the typical rural region of the LAP area soils of moderate (22\%) and good (31\%) quality prevailed. The soil quality index is a product of a few selected soil indicator properties and is a useful method with which to differentiate between the degradation status of various soils (Masto et al., 2015). Our studies revealed that the quality of soils should be determined by analysing both physicochemical and biological soil characteristics, and in the agricultural regions exposed to anthropogenic activity the level of contamination should be incorporated into the SQI evaluation.

Table 4. Classification criteria of the soil quality for the minimum data set (Li et al. 2018)

\begin{tabular}{lccccc}
\hline & \multicolumn{5}{c}{ Soil quality grade } \\
\cline { 2 - 5 } Indicator & Grade 1 & Grade 2 & Grade 3 & Grade 4 & Grade 5 \\
\cline { 2 - 6 } & Very high & High & Moderate & Low & Very low \\
\hline SQI & $>0.60$ & $0.55-0.60$ & $0.45-0.54$ & $0.38-0.44$ & $<0.38$ \\
\hline
\end{tabular}

SQI - soil quality index. 


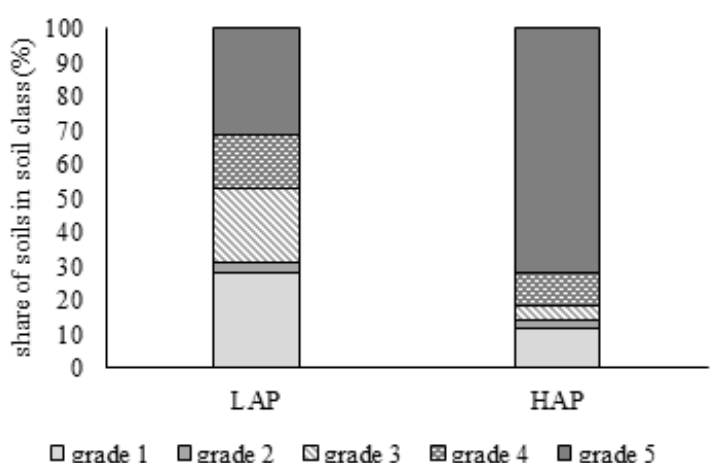

Fig. 2. Classification of the SQI values for the area under study, percentage share of soils in specific soil quality grades according to the criteria proposed by Li et al. (2018), LAP - area of low anthropopressure, HAP - area of high anthropopressure.

\section{CONCLUSIONS}

1. The soils from the regions investigated differed significantly in their biological activity and levels of pollution (heavy metals ad PAHs content).

2. Different soil descriptors were included in the minimum data set; total nitrogen content, potential of nitrification, sand content and dehydrogenase activity for the area of low anthropopressure, and humins, Zn content, basal microbial respiration, $\mathrm{pH}$ and silt for the area of high anthropopressure.

3 . The level of anthropopressure was an important factor influencing soil quality; significantly higher soil quality index values (average of 0.50 ) were determined for the area of low anthropopressure.

4. The majority $(80 \%)$ of the soil samples from the region of high anthropogenic pressure was classified as low quality soil.

Conflict of interest: The Authors do not declare any conflict of interest.

\section{REFERENCES}

Armenise E., Redmile-Gordon M.A., Stellacci A.M., Ciccarese A., and Rubino P., 2013. Developing a soil quality index to compare soil fitness for agricultural use under different managements in the Mediterranean environment. Soil Till. Res., 130, 91-98. https://doi.org/10.1016/j.still.2013.02.013

Asensio V., Guala S.D., Vega F.L., and Covelo E.F., 2013. A soil quality index for reclaimed mine soils. Environ. Toxicol. Chem., 32, 2240-2248. https://doi.org/10.1002/etc.2315

Bastida F., Zsolnay A., Hernández T., and García C., 2008. Past, present and future of soil quality indices: A biological perspective. Geoderma, 147, 159-171. https://doi. org/10.1016/j.geoderma.2008.08.007

Bera T., Collins H.P., Alva A.K., Purakayastha T.J., and Patra A.K., 2016. Biochar and manure effluent effects on soil biochemical properties under corn production. Appl. Soil Ecol., 107, 360-367. https://doi.org/10.1016/j. apsoil.2016.07.011
Bünemann E.K., Bongiorno G., Bai Z., Creamer R.E., De Deyn G., de Goede R., Fleskens L., Geissesn V., Kuyper T.W., Mäder P., Pulleman M., Sukkel W., van Groenigen J.W., and Brussaard L., 2018. Soil quality - A critical review. Soil Biol. Biochem., 120, 105-125. https://doi. org/10.1016/j.soilbio.2018.01.030

Casida L., Klein D., and Santoro T., 1964. Soil Dehydrogenase Activity. Soil Science, 98, 371-376. https://doi. org/10.1097/00010694-196412000-00004

Central Statistical Office, 2015. Local Data Bank. http://stat.gov. $\mathrm{pl} / \mathrm{bdlen} / \mathrm{app} /$ strona.html?p_name=indeks).

Epelde L., Burges A., Mijangos I., and Garbisu C., 2014. Microbial properties and attributes of ecological relevance for soil quality monitoring during a chemical stabilization field study. App. Soil Ecol., 75, 1-12. https://doi. org/10.1016/j.apsoil.2013.10.003

Garrigues E., Corson M.S., Angers D.A., van der Werf H.M.G., and Walter Ch., 2012. Soil quality in Life Cycle Assessment: Towards development of an indicator. Ecol. Indicators, $18, \quad 434-442 . \quad$ https://doi.org/10.1016/j. ecolind.2011.12.014

ISO 10381-6, 1993. Soil quality-Sampling-Guidance on the collection, handling and storage of soil for the assessment of aerobic microbial processes in the laboratory. Geneva, Switzerland.

ISO 10390, 2005. Soil quality-Determination of $\mathrm{pH}$. Geneva, Switzerland.

ISO 12782-4, 2012. Soil quality - Parameters for geochemical modelling of leaching and speciation of constituents in soils and materials - Part 4: Extraction of humic substances from solid samples. Geneva, Switzerland.

ISO 16072, 2002. Soil quality - Laboratory methods for determination of microbial soil respiration. Geneva, Switzerland.

ISO 11466, 1995. Soil quality - Extraction of trace elements soluble in aqua regia. Geneva, Switzerland.

ISO 14240-1, 1997. Soil quality - Determination of soil microbial biomass - Part 1: Substrate-induced respiration method. Geneva, Switzerland.

Klimkowicz-Pawlas A., Smreczak B., and Ukalska-Jaruga A., 2017. The impact of selected soil organic matter fractions on the PAH accumulation in the agricultural soils from areas of different anthropopressure. Environ. Sci. Pollut. Res., 24, 10955-10965. https://doi.org/10.1007/ s11356-016-6610-8

Li X., Li H., Yang L., and Ren Y., 2018. Assessment of soil quality of croplands in the corn belt of Northwest China. Sustainability, 10, 248, https://doi.org/10.3390/su10010248

Maliszewska-Kordybach B., Klimkowicz-Pawlas A., Smreczak B., and Janusauskaite D., 2007. Ecotoxicological effect of phenanthrene on nitrifying bacteria in soils of different properties. J. Environ. Quality, 36, 1635-164. https://doi. org/10.2134/jeq2007.0118

Maliszewska-Kordybach B., Klimkowicz-Pawlas A., Smreczak B., and Stuczyński T., 2010. Relationship between soil concentrations of PAHs and their regional emission indices. Water Air Soil Pollut., 213, 319-330. https://doi. org/10.1007/s11270-010-0387-z

Masto R.E., Sheik S., Nehru G., Selvi V.A., George J., and Ram L.C., 2015. Assessment of environmental soil quality 
around Sonepour Bazari mine of Raniganj coalfield, India. Solid Earth, 6, 811-821. https://doi.org/10.5194/ se-6-811-2015

Muhlbachova G., Sagova-Mareckova M., Omelka M., Szakova J., and Tlust P., 2015. The influence of soil organic carbon on interactions between microbial parameters and metal concentrations at log-term contaminated site. Sci. Total. Environ., 502, 218-223.

https://doi.org/10.1016/j.scitotenv.2014.08.079

Mukherjee A. and Lal R., 2014. Comparison of soil quality index using three methods. PLoS ONE, 9(8), e105981. https://doi.org/10.1371/journal.pone.0105981

Myśków W., Stachyra A., Zięba S., and Maciak D., 1996. Biological activity of soil as an index of its fertility (in Polish). Soil Science Annual, 47(1/2), 89-100.

PN-R-04032, 1998. Soils and mineral soil materials. Soil sampling and determination of particle size distribution in mineral soil material (in Polish).

Rahmanipour F., Marzaioli R., Bahrami H.A., Fereidouni Z., and Bandarabadi S.R., 2014. Assessment of soil quality indices in agricultural lands of Qazvin Province, Iran. Ecol. Indicators, 40, 19-26. https://doi.org/10.1016/j. ecolind.2013.12.003

Swift R.S., 1996. Organic matter characterization. In: Methods of soil analysis. Part 3. Chemical methods - SSSA Book Series no. 5 Soil Science Society of America and American Society of Agronomy, 1011-1068. https://doi.org/10.2136/ sssabookser5.3
Tan K., 2014. Humic Matter in Soil and Environment. Principles and Controversies, CRC Press, Taylor and Francis Group, Boca Raton, London, New York., USA.

Vasu D., Singh S.K., Ray S.K., Duraisami V.P., Tiwary P., Chandran P., Nimkar A.M., and Anantwar S.G., 2016. Soil quality index (SQI) as a tool to evaluate crop productivity in semi-arid Deccan plateau, India. Geoderma, 282, 70-79. https://doi.org/10.1016/j.geoderma.2016.07.010

Volchko Y., Norrman J., Rosén L., Berknut M., Joseffson S., Söderqvist T., Norberg T., Wiberg K., and Tysklind M., 2014. Using soil function evaluation in multi-criteria decision analysis for sustainability appraisal of remediation alternatives. Sci. Total Environ., 485-486, 785-791. https://doi.org/10.1016/j.scitotenv.2014.01.087

Watanabe A., Sarno J., Rumbanraja K., and Tsutsuki M.K., 2001. Humus composition of soils under forest, coffee and arable cultivation in hilly areas of south Sumatra, Indonesia. Europ. J. Soil Sci., 52, 599-606. https://doi.org/10.1046/j.1365-2389.2001.00410.x

Wyszkowska J., Borowik A., Kucharski M., and Kucharski J., 2013. Applicability of biochemical indices to quality assessment of soil polluted with heavy metal. J. Elem., 18(4), 723-732. https://doi.org/10.5601/jelem.2013.18.4.504

Wyszkowska J. and Kucharski J., 2004. The nitrification in the soil by heating oil contaminated (in Polish). Soil Science Annual, 55(2) 517-525. 